\title{
極大地震動の入力制限をはかる直置き型構造の 滑り挙動と最大ベースシア \\ SLIPPING BEHAVIOR OF BASE SHEAR CAPPING BUILDINGS FOR COLLAPSE PREVENTION AND REQUIRED MAXIMUM STRENGTH
}

\author{
濱嶋郁望*, 倉田真宏**, 中島正愛*** \\ Ikumi HAMASHIMA, Masahiro KURATA and Masayoshi NAKASHIMA
}

\begin{abstract}
This study proposes a seismic retrofit method named 'base shear capped building', which detaches the superstructure from foundation. The paper verifies the effectiveness of proposed system by shake table test and numerical simulation. The shake table test shows basic properties of sliding behavior. In numerical simulation, the proposed system is simplified to an SDOF system having a sliding base. In pulse type earthquakes having a magnitudes of larger than level 2, the maximum value remains at most 2.5 times of the friction coefficient. If slight ductility is permitted, the maximum base shear can be reduced to twice the friction coefficient.
\end{abstract}

Keywords : Base shear capped buildings, Seismic retrofit, sliding, friction coefficient, Maximum base shear 直置き型構造, 而震補強, 滑り, 摩擦係数, 最大ベースシア係数

\section{1. はじめに}

地震に対して脆弱な地域は世界に数多く存在する。そのような地 域の建物の多くは極大地震動に対して耐震能力が十分でないため倒 壊し、多くの死傷者を生み出寸危険性が高い。地震時において人命 の確保は最優先事項であって、極大地震に対しては相当損傷したと しても建物全体は倒壊を避けなければならない。本論では、極大地 震動に対して脆弱な建物に適用寸る耐震補強法の一つとして、直置 き型構造を検討する。直置き型構造とは、上部構造と基礎を切り離 した構造であり、極大地震時に上部構造が基礎に対して滑ることに より、上部構造への入力を制限し、建物全体の倒壊を防ぐものであ る。人命確保のために建物全体倒壊という最悪な場合を避けるため の耐震補強法であるため、残留変位を含め地震後の継続利用等につ いてはそれを一義的には考えないこととする。

既往の研究では滑り挙動に関して解析的、実験的検討がなされて いる。Mostagel ら 1 2) は、滑りが生じる基礎部と上部構造部をそれ ぞれを一質点とした二質点系の運動方程式を解くことで滑り挙動を 理論的に示しており、建物全体質量に対する上部構造の質量の割合 （以降質量比と称する）が滑り挙動において支配的なパラメータで あることを示している。実建物を柱脚等の基礎部と上部構造部に分 けて考えた場合、建物全体に対して上部構造部が占める質量の割合 は当然のことながら大きく、質量比は 1 に近いと考えられる。上述 の理論展開ではさらに、質量比が 0.8 の場合、最大ベースシア係数 は摩擦係数の約 2 倍となる場合が示されている。欧州等での地震に
対して脆弱な建物の最大耐力の相場が（非構造部材等の文献も含め

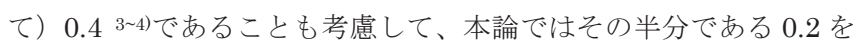
摩擦係数の目標值とした。既往の実験によると、一般的な建築材料 である鋼とモルタル間の摩擦係数はおよそ 0.8 5)である。摩擦係数を 小さくするためにはさまざまな方法があるが、文献[6]では入手が容 易で安価な黒鉛潤滑剂を鋼とモルタル間に塗付するだけで摩擦係数 は約 0.2 まで下げることが示されている。そこで本研究での基礎部 には同材料を用いることとした。

滑り時にロッキングを起こさないために、ここでは対象建物は低 層とし、また対象建物に甚大な被害を与える可能性の高いパルス入 力波に対する最大ベースシア係数を評価することとした。まず、振 動台実験により滑り挙動の基本性能を評価する。次いでパルス性入 力波の基本性状を確かめるためにインパルス波に対する上部構造へ の最大ベースシアの上限について数值解析により確認し、それを踏 まえてパルス性の高い複数の地震動に対する最大ベースシアを解析 上で評価する。本論では極大地震に対して上部構造を弾性に留める 場合の上限（最大ベースシア）を主たる議論の対象とするが、上部 構造の塑性化を一部許容した場合の挙動についても数值解析を用い て考察する。

\section{2. 振動台実験による性能評価}

\section{1 実験概要}

本節では滑り挙動の基本特性を振動台実験を用いて検証する。そ
* 京都大学工学研究科建築学専攻 大学院生

** 京都大学防災研究所 准教授.Ph.D.

*** 京都大学防災研究所 教授.Ph.D.
Grad. Student, Graduate School of Eng., Kyoto University Assoc. Prof., DPRI, Kyoto University, Ph.D. Prof., DPRI, Kyoto University, Ph.D. 


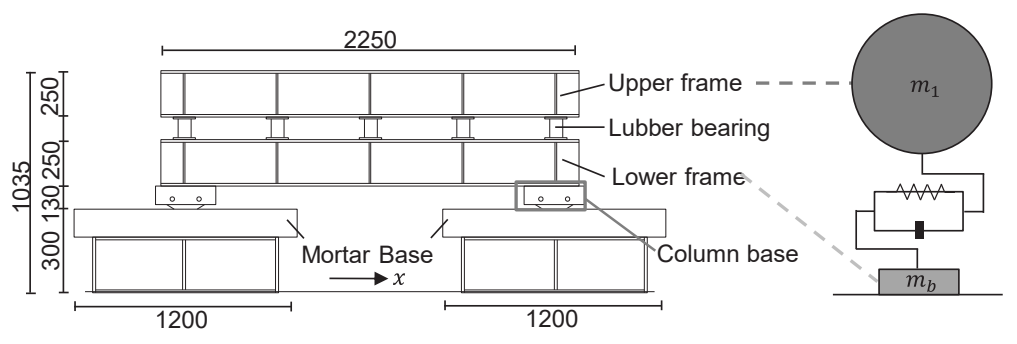

(a) Basic specimen

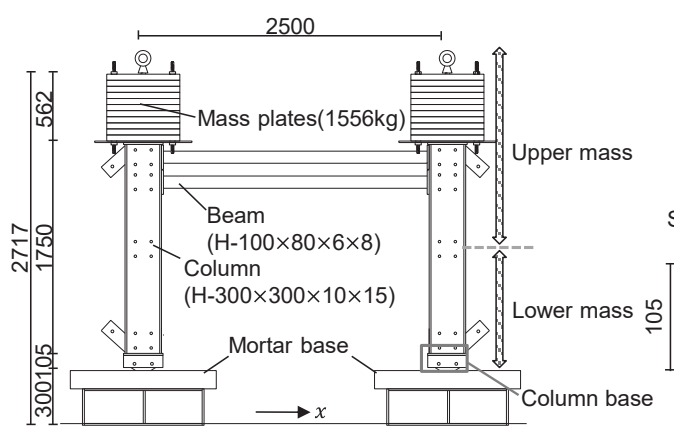

(b) Frame specimen

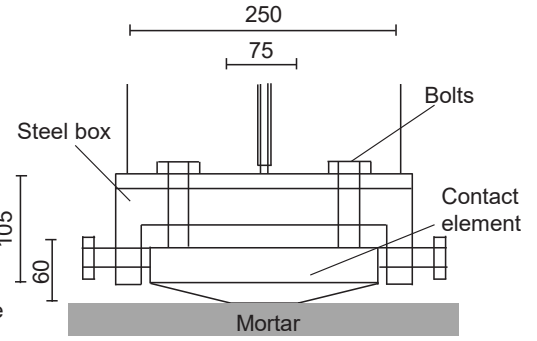

(c) Section of column base

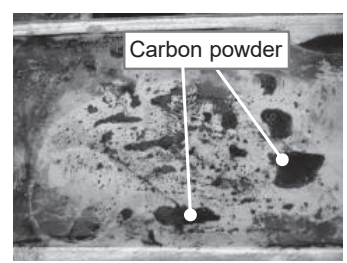

(d) Surface of mortar base

Fig. 1 Details of the test specimen (Unit:mm)

のために上部構造と柱脚をそれぞれ一質点とした基本試験体と、転 倒モーメントによる軸力変動が生じる骨組試験体を設計した。前者 を用いた実験を「実験 1 、後者を用いた実験を「実験 $2 」$ と称する。 対象建物は低層建物を想定しているため、全ての試験体の基礎固着 時の固有振動数を約 $3 \mathrm{~Hz}$ とした。

Fig. 1 に試験体概要を示す。Fig.1(a)は基本試験体とモルタル基礎 の立面図である。右側に示すような上部質量 $m_{1}$ と下部質量 $m_{b}$ から 構成される二質点を模擬している。鋼製の上部フレームと下部フレ 一ムから構成され、両フレーム間に積層ゴムを挿入することで柔性 と減衰を付与している。上下フレームには鋼板を載せることができ、 上部フレームの質量は $m_{1}$ 、下部フレームの質量は $m_{b}$ に対応してい る。全体質量 $5015 \mathrm{~kg}$ を一定として、上下フレームに載せる鋼板量 を調節して質量比を変えた。

Fig.1(b)は骨組試験体とモルタル基礎の立面図である。骨組試験 体は 4 本の剛な柱と 8 つの梁で構成されている。強加振下において も試験体を弾性に留めるため、柱は十分な強度を保持するように $\mathrm{H}-300 \times 300 \times 10 \times 15$ を用いた。一方固有振動数を約 $3.0 \mathrm{~Hz}$ とするた め、梁は柔らかい部材とし $\mathrm{H}-100 \times 80 \times 6 \times 8$ を用いた。骨組におい て柱の高さ中央を基準としてそれより上の質量を上部質量、それよ り下の質量を下部質量とする。実建物の質量比を想定して骨組試験 体の質量比を 0.9 に設定し、計 $1556 \mathrm{~kg}$ の鋼板を各柱上部に載せた。 全体質量は $7578 \mathrm{~kg}$ である。スパン長さと高さは、転倒モーメント のつり合い式から柱脚の浮き上がりが起きないアスペクト比の最大 值が 0.7 であったことと、実験室の高さ制限により決めた。試験体 の特性を Table 1 にまとめる。基本試験体の質量比は 3 種類検討し、 それぞれ SF-1、SF-2、SF-3 と称する。骨組試験体の質量比は 0.91 であり、これを TTB と称する。なお基礎固着時は柱脚下部がピン 挙動をし、固有振動数はホワイトノイズ加振により同定した。
Table1 Properties of specimens

\begin{tabular}{|c|c|c|c|}
\hline & Specimen & Mass ratio $(\alpha)$ & $\begin{array}{c}\text { Natural } \\
\text { frequency } \\
(\mathrm{Hz})\end{array}$ \\
\hline \multirow{3}{*}{ Basic specimen } & SF-1 & 0.5 & 3.58 \\
\cline { 2 - 4 } & SF-2 & 0.6 & 3.00 \\
\cline { 2 - 4 } & SF-3 & 0.8 & 2.77 \\
\hline Frame specimen & TTB & 0.9 & 3.17 \\
\hline
\end{tabular}

Fig.1(c) (d)には基礎部の詳細を示す。Fig.1(c)は柱脚断面で、箱 型要素とベースプレートを模擬した鋼柱要素で構成されている。 柱脚は基本試験体では下部フレームの下側の四隅、骨組試験体では 各柱下端に取り付けられており、それらがモルタル上を滑ることに より直置き型構造の滑り挙動を再現している。鋼柱要素の上側の断 面は $250 \mathrm{~mm} \times 250 \mathrm{~mm}$ であり、滑りに十分な軸力応力を得るため 滑り面は $75 \mathrm{~mm} \times 75 \mathrm{~mm}$ に減じている。実験 1 で用いた試験体の 軸力応力は $2.2 \mathrm{MPa}$ 、実験 2 で用いた試験体の軸力応力は $3.3 \mathrm{MPa}$ であった。Fig.1(d)は黒鈶潤滑剤を塗付後のモルタル基礎表面を示 す。写真の黒い部分は、モルタル表面の凹凸部分に入り込んだ黒鉛 であり表面の多少の凹凸を平らにする効果がある。モルタル基礎の 大きさは $1200 \mathrm{~mm} \times 550 \mathrm{~mm}$ であり、試験体をモルタル基礎の中央 に設置してモルタル基礎の長辺方向に一方向加振すると、最大で土 $550 \mathrm{~mm}$ の滑り変位を許容する。加振方向は Fig.1 中の $\mathrm{x}$ 方向であ る。入力波は正弦波と地震波を用い、正弦波入力の振動数を $4.0 \mathrm{~Hz}$ 、 $2.0 \mathrm{~Hz} 、 1.5 \mathrm{~Hz} 、 1.0 \mathrm{~Hz} 、 0.5 \mathrm{~Hz}$ とした。地震動は ElCentro 波、JMA Kobe NS 波、JMA Kobe EW 波を用い、滑り変位が最大許容滑 り変位である $550 \mathrm{~mm}$ に達するまで漸増加振した。なお本実験の詳 細は[7]に記載している。

\section{2 摩擦係数の安定性}

まず、摩擦係数の評価方法を説明する。式(1)は二質点系の釣り合 いより求めている。

$$
\mu=\frac{m_{1} a_{1}+m_{b} a_{b}}{\left(m_{1}+m_{b}\right) g}
$$




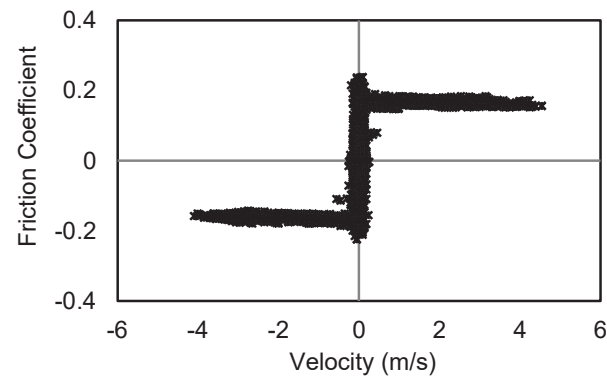

(a) Relationship between Velocity and Friction Coefficient

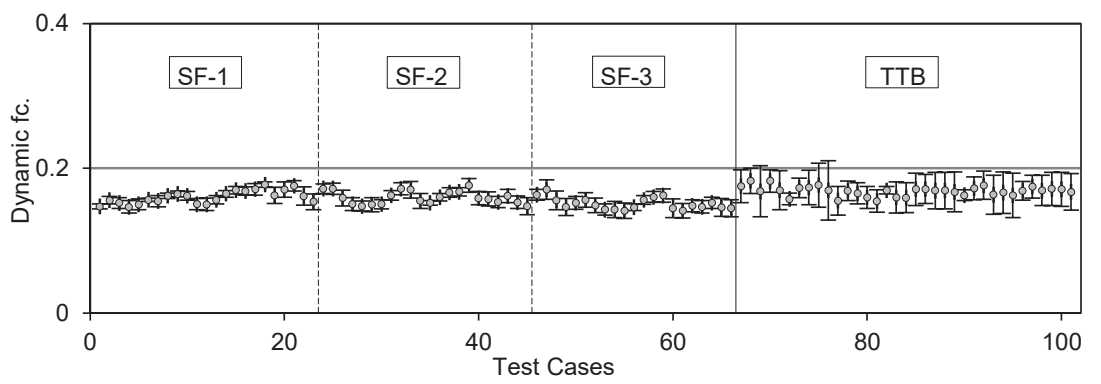

(b) Variation of dynamic friction coefficients

Fig. 2 Friction Coefficient

ここで、 $\mu$ は摩擦係数、 $m_{1}$ と $m_{b}$ は上部質量と下部質量、 $a_{1}$ と $a_{b}$ は上 部と下部の加速度、gは重力加速度である 8)。 $a_{1} 、 a_{b}$ に関して、基 本試験体では上部フレームと下部フレームに設置した加速度計、骨 組試験体では柱上端と下端に設置した加速度計から得た。Fig.2 (a) に最大振幅が $2 \mathrm{~m} / \mathrm{s}^{2}$ の正弦波 $1 \mathrm{~Hz}$ を入力した SF-3（質量比が 0.8） の滑り速度 (横軸) と摩擦係数（縦軸）の関係を示す。滑り速度は、 レーザー変位計から得た滑り変位を時間について微分することによ り求めた。滑り速度が $0 \mathrm{~m} / \mathrm{s}$ の場合が静止摩擦係数であり、滑り始 め速度が増加すると摩擦係数は静止摩擦係数よりも減る傾向にあり、 これが動摩擦係数である。Fig.2(a)より、滑り挙動を支配する動摩 擦係数は滑り速度の増加によって顕著な変化は見られなかった。

本実験では計 101 回加振をし、累計滑り量は約 $20 \mathrm{~m}$ であった。 101 回の加振ごとにそれぞれで得られた動摩擦係数の平均值と標準 偏差を Fig.2(b)に示す。図中の丸印は平均值、棒は土標準偏差であ る。平均值は、基本試験体、骨組試験体ともに 0.16 であった。また 標準偏差の最大值は基本試験体で 0.01、骨組試験体で 0.04 であり、 変動係数に換算すると基本試験体で 0.06、骨組試験体で 0.25 と小 さく、累計滑り量が $20 \mathrm{~m}$ に達したにも関わらず動摩擦係数の増減は 僅かであり、摩擦係数は 0.16 で安定していた。

\section{3 数值解析モデル}

予備解析のため、数值解析コード OpenSees 9)を用いて基本試験 体と骨組試験体の数值解析モデルを構築した。基本試験体は Fig.1(a)の右に示すような上部質量 $m_{1}$ と下部質量 $m_{b}$ から構成され る二質点系モデルで模擬した。 $m_{1}$ と $m_{b}$ 間は “Zerolength Element” と呼ばれる長さをもたない線形ばね要素で連結されており、試験体 の剛性 $K$ と粘性減衰 $C$ を付与した。減衰定数は実験で観測された加速 度時刻歴の減衰状態から $2 \%$ とした。

骨組試験体は Fig.3(a)に示す 1 層 1 スパン 3 次元モデルで模擬し た。柱と梁は“Elastic Column Beam Element”と呼ばれる要素を用 いて柱と梁を模擬した。各柱上端には錘の質量を与え、柱の質量は 柱長さに沿って 10 個に分散させた。減衰定数は実験で得られた応 答加速度減衰状態からレイリー減衰を用い、一次モードに $2.7 \%$ 、二 次モードに $1.5 \%$ の減衰定数を与えた。

基本試験体と骨組試験体の数值解析モデルの滑り部分には“Flat Slider Bearing”要素を用いて滑り挙動を模擬した。Fig.3(b)に変位 一摩擦係数関係を示す。滑り出すまでは固着状態を模擬するため極 めて高い剛性 $K_{\text {init }}$ を与え、滑り出すと剛性が 0 になるという完全弾 塑性系を用いた。摩擦係数は実験結果から 0.16 とし、滑り速度に依

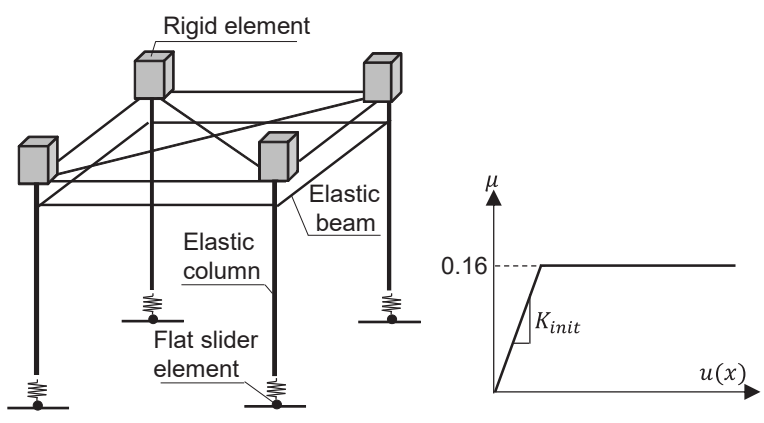

(a) TTBmodel

(b) SI ippage-Friction Coefficient

Fig. 3 Modeling of Numerical Analysis

Table2 Properties of numerical models

\begin{tabular}{|c|c|c|c|c|c|c|}
\hline & $\begin{array}{c}\text { Mass } \\
\text { ratio }\end{array}$ & $\begin{array}{c}\text { Total } \\
\text { weight(kg) }\end{array}$ & $\begin{array}{c}\text { Upper } \\
\text { mass } \\
(\mathrm{kg})\end{array}$ & $\begin{array}{c}\text { Lower } \\
\text { Mass } \\
(\mathrm{kg})\end{array}$ & $\begin{array}{c}\text { Natural } \\
\text { Freq. } \\
(\mathrm{Hz})\end{array}$ & $\begin{array}{c}\text { Stiff. } \\
\left(\times 10^{6}\right. \\
\mathrm{N} / \mathrm{m})\end{array}$ \\
\hline SF-1 & 0.50 & & 2515 & 2500 & 3.5 & 1.22 \\
\cline { 1 - 4 } SF-2 & 0.64 & \multirow{2}{*}{5015} & 3210 & 1805 & 3.0 & 1.14 \\
\cline { 1 - 4 } SF-3 & 0.78 & & 3910 & 1105 & 2.8 & 1.21 \\
\hline TTB & 0.91 & 7578 & 6910 & 668 & 3.2 & \\
\hline
\end{tabular}

存せず一定とした。数值解析パラメータは Table 2 に示す。

\section{4 基本挙動の特性}

Mostaghel ら 1 2)によると、式(2)に示すような滑り時に特有の振 動数 $\omega^{\prime}$ と減衰方がみられ、これらは質量比 $\alpha$ に依存する。

$$
\omega^{\prime}=\frac{\omega_{n}}{\sqrt{1-\alpha}}, \quad \xi^{\prime}=\frac{\xi}{\sqrt{1-\alpha}}, \quad \alpha=\frac{m_{1}}{m_{1}+m_{b}}
$$

最大振幅 $6 \mathrm{~m} / \mathrm{s}^{2}$ の正弦波 $1.50 \mathrm{~Hz}$ を入力した場合の $\mathrm{SF}-1$ (質量比が 0.5）の上部加速度の時刻歴の一部を Fig. 4 に示す。Fig.4より主な 振動数は $1.5 \mathrm{~Hz}$ で入力波の振動数と対応するが、これとは別に 5.10 $\mathrm{Hz}$ の高振動数で振動している。式(2)を参照すれば $\omega^{\prime}$ は $5.06 \mathrm{~Hz}$ で あり、実験值と一致する。このように、滑り時に特有の高振動応答 が現れる。

\section{5 骨組試験体の挙動}

軸力変動が柱間で大きい場合、柱脚と基礎間に生じる摩擦力が柱 脚間で值が異なり、4つの柱脚の挙動がばらつくために安定した滑 り挙動を示さないことが危惧される。そこで骨組を用いた実験 2 で は、軸力変動が滑り挙動に及ぼす影響を検証する。Fig.5(a)は最大 振幅 $8 \mathrm{~m} / \mathrm{s}^{2}$ の正弦波 $1.50 \mathrm{~Hz}$ 入力に対する前面柱の軸力変動の時刻 歴、Fig.5(b)は同入力波に対する前面柱の滑り変位の時刻歴を示す。 Fig.5(a)の縦軸において $N_{1} 、 N_{2}$ は前面に位置する 2 つの柱に取り付 


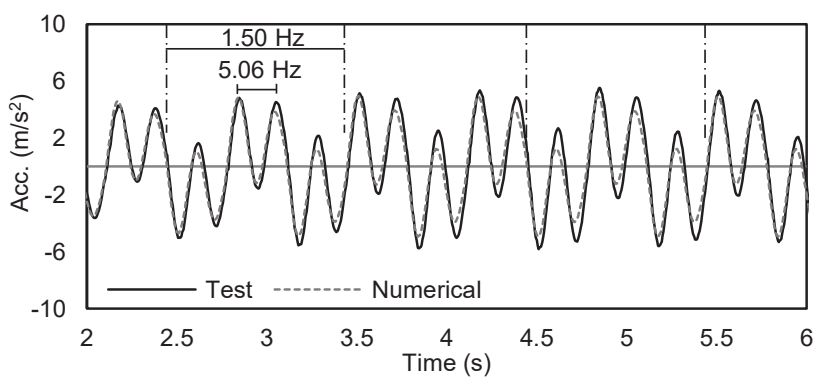

Fig. 4 Time histories of response accelerations (sine $1.50 \mathrm{~Hz}$ ) けたひずみゲージの值から得た軸力、ここで $N_{g}$ は鉛直荷重で $N_{g}$ は $18.6 \mathrm{kN}$ である。Fig.5(a)より、加振後 0.146 秒間は両柱とも值は 1 を保っている。つまり、軸力 $N_{1} 、 N_{2}$ は鉛直荷重 $N_{g}$ と等しく、軸力変 動は起こっていない。これは加振が計測開始から 0.146 秒後に加振 を開始したことによる。その後、加振中に 1 を中心に最大 $\pm 40 \%$ の 変動がある。Fig.5(b)は同入力波を入力した場合の前面柱脚 2 つの 滑り変位の時刻歴を示す。 2 つの柱脚の滑り変位の差の最大值は、 2.45 秒後の $3.4 \mathrm{~mm}$ であり、最大滑り変位の僅か $1.4 \%$ に留まって いる。これらから、軸力変動が最大で $40 \%$ あ゙っても個々の柱脚は ほぼ同時に滑り出し安定した滑り挙動を示したことが分かる。

\section{6 最大ベースシア係数}

Fig.6 に全試験体に JMAKobeNS 波を漸増入力した場合の最大心゙ ースシア係数を示す。最大ベースシア係数は、基本試験体の場合は、 上部フレームに設置した 4 つの加速度計データの最大值、骨組試験 体の場合は柱の上端に設置した加速度計データの最大值を重力加速 度で除することにより得た。図中のマーカーは実験結果、実線と点 線は対応する解析結果を示す。

基本試験体の実験結果と解析結果の比較により、誤差の最大值は、 SF-1 で 4\%、SF-2 で 18\%、SF-3 で 23\%と、概整合している。ま た、質量比が大きいほど応答は小さい。これは式(2)で示した減衰 $\xi^{\prime}$ が質量比の増加とともに増加することが主因とされている。また、 TTB を二質点に簡略化した数值解析モデルの応答を灰色の一点鎖

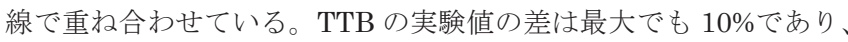
最大応答において軸力変動の影響は顕著ではないと判断できる。

以上より、質量比が 0.9 である TTB の挙動は、転倒モーメントに よる軸力変動を無視した二質点系に簡略化できると考えられる。以 降の数值解析では直置き型構造を Fig.1(a)右側の図と同様の二質点 系として最大応答を考察する。

\section{3. パルス性入カに対する最大応答}

\section{1 数值解析モデルと入力波の特性}

本章では、低層建物に甚大な被害を与える可能性の高いインパル ス入力に対する最大ベースシア係数を数值解析によって検討する。 数值解析モデルは、上部構造と柱脚をそれぞれ一質点とした二質点 系で、質量比を 0.9 、固有周期を 0.3 秒、摩擦係数を 0.16 とする。 上部質量 $m_{1}$ は $9.0 \times 10^{5} \mathrm{~kg}$ 、下部質量は $1.0 \times 10^{5} \mathrm{~kg}$ とし、初期剛性は $3.9 \times 10^{5} \mathrm{kN} / \mathrm{m}$ である。減衰定数は基本的に $5 \%$ とし、理論展開の場 合のみ簡単のため $0 \%$ とする。

入力波は 2 種類のパルス性入力波を用いる。まず、パルス入力波 の基本性状を確かめるために、継続時間が式(2)で示した滑り時に特

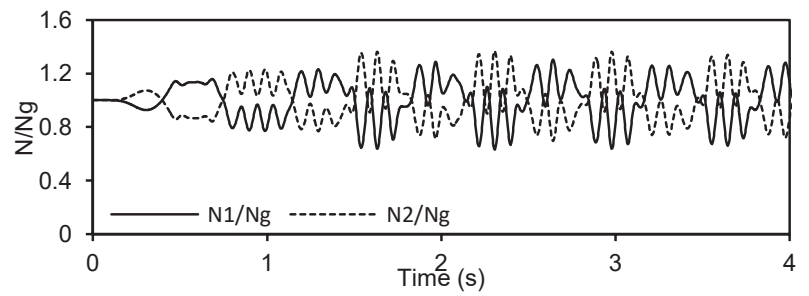

(a) Axial force of front columns

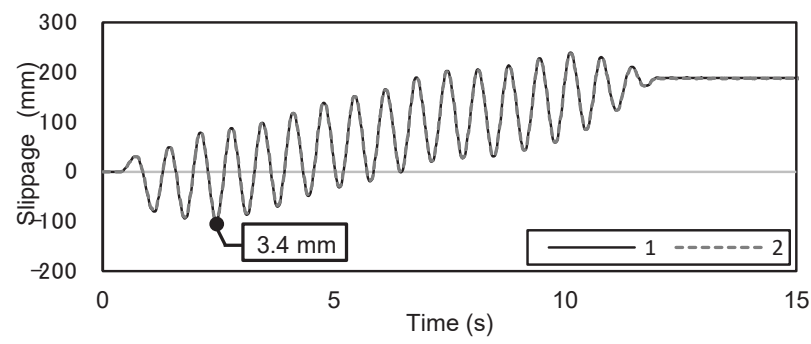

(b) SI ippage of front columns

Fig. 5 Time history responses of TTB (sine $\left.1.5 \mathrm{~Hz} 8 \mathrm{~m} / \mathrm{s}^{2}\right)$

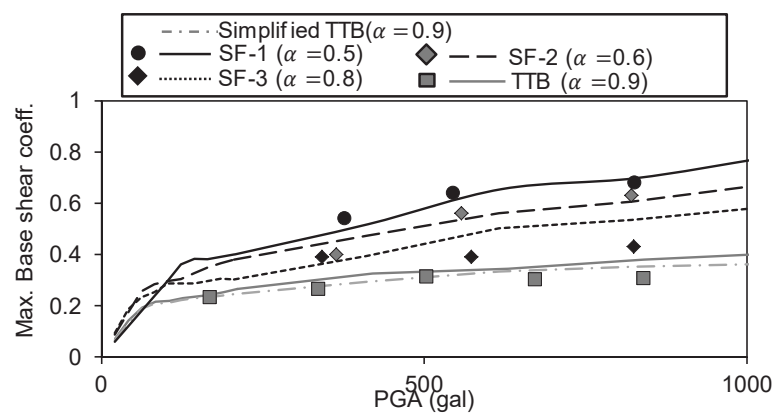

Fig. 6 Max base shear coefficients (JMAKobe NS)

有の振動数 $\omega^{\prime}$ の周期の $1 / 10$ と微小でありほぼ 0 とみなせる波（イ ンパルス波）を用いる。

2 つめのパルス性入力波は、パルス性の高い 20 の地震動を含む $\mathrm{SAC} 20$ 地震動 (再現期間 475 年) 10 11)を用いた。SAC20 地震動は、 パルス成分を多く含み、ロサンゼルス市域の地震ハザードが日本の 都市部に近く、かつ地震動の大きさは二次設計レベルの想定に近い。 Fig. 7 にSAC20 地震動の応答スペクトルを示している。灰色の実線 は 20 の地震動それぞれの応答スペクトルであり、黒色の実線はそ れらの平均值を示す。この図から、 SAC20 の平均的な卓越周期はお よそ 0.3 秒であり、固有周期 0.3 秒の数值解析モデルの応答を増幅 させる。

\section{2 インパルス入カに対する最大ベースシア}

インパルス入力波を漸増入力した二質点系の最大ベースシア係数 を Fig.8(a)に示す。ここでは減衰を簡単のため $0 \%$ とする。最大べー

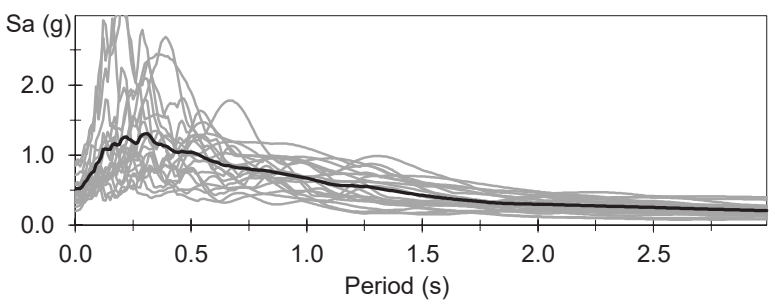

Fig. 7 Response spectra of SAC20 


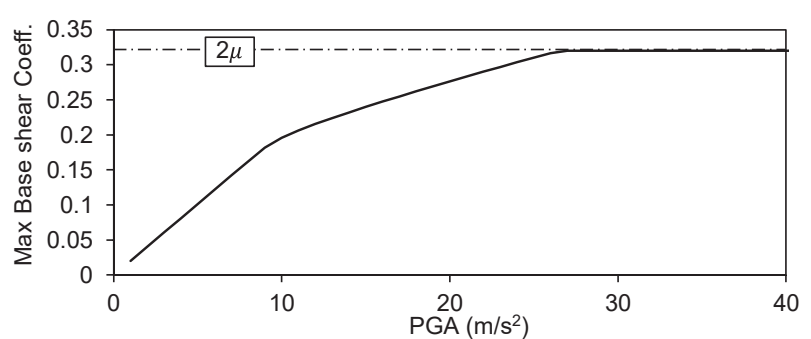

(a) Impulse

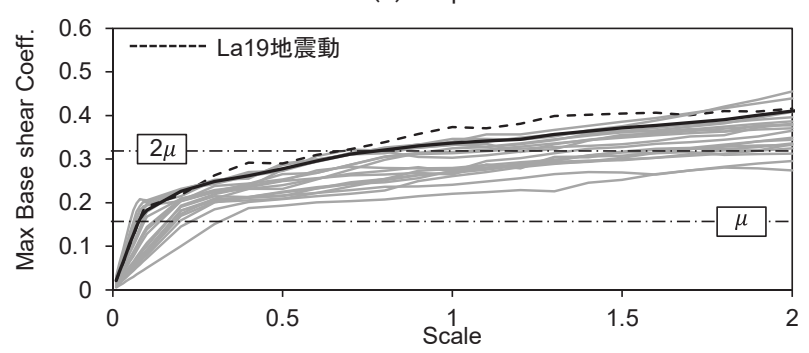

(b) SAC20 motions

Fig. 8 Maximum base shear coefficients

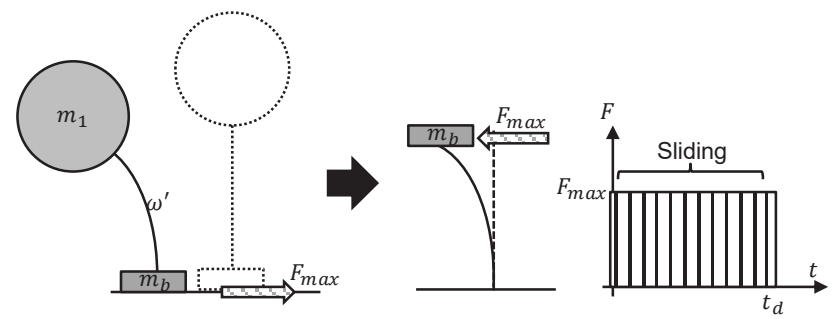

(a) SI iding behavior of 2 mass system (b) behvarior of $m_{1}$ against $m_{b}$

Fig. 9 Modeling of sliding behavior

スシア係数は、上部質量 $m_{1}$ と下部質量 $m_{b}$ 間に作用するせん断力を 上部重量 $m_{1}$ gで除した值の最大值である。Fig.8(a)より、およそ 10 $\mathrm{m} / \mathrm{s}^{2}$ までは $m_{b}$ と滑り面に生じる摩擦力が最大静止摩擦力を超えず 滑りが生じないため、上部質量 $m_{1}$ の一質点の挙動となり、最大ベー スシア係数は線形的に増加する。入力波がそれ以上になると滑りが 生じることにより系への入力が低減されるため最大ベースシア係数 の増加率は緩やかになり、最終的に一定值 $2 \mu$ (摩擦係数の 2 倍）に 達する。

二質点系の滑り時の挙動は、Fig.9(a)に示すように、 $m_{b}$ が滑って いる間は、 $m_{1}$ は滑り時の高振動数 $\omega^{\prime}$ で振動し、 $m_{b}$ には最大静止摩 擦力 $F_{\text {max }}$ が作用している。この挙動を $m_{1}$ に対する $m_{b}$ の相対挙動とみ ると、Fig. $9(\mathrm{~b})$ のよに固有振動数 $\omega^{\prime}$ で質量 $m_{b}$ の一質点系に $F_{\text {max }}$ が 動的に作用している挙動とみなせる。この場合の $m_{b}$ の変位応答を $X(t)$ とすると、式(3)で表すことができる 12 13)。

$$
\left\{\begin{array}{c}
X(t)=x_{\text {static }}\left(1-\cos \frac{2 \pi}{T_{n}} t\right)\left(t \leq t_{d}\right) \\
X(t)=x_{\text {static }}\left(\sin \frac{\pi t_{d}}{T_{n}}\right) \sin \left[2 \pi\left(\frac{t}{T_{n}}-\frac{1}{2} \frac{t_{d}}{T_{n}}\right)\right]\left(t>t_{d}\right)
\end{array}\right.
$$

ここで $x_{\text {static }}$ は $F_{\text {max }}$ が静的に作用寸る場合の $m_{b}$ の静的変位、 $\omega^{\prime}=$ $2 \pi / T_{n} 、 t_{d}$ は滑り時間である。滑り時に変位応答は最大值に達するの で式(3)上段に着目すると最大值は静的変位 $x_{\text {static }}$ の 2 倍となる。最 大值 $2 x_{\text {static }}$ に達するかどうかは $t_{d} / T_{n}$ の值に依存し、0.5 以上となれ ば $2 x_{\text {static }}$ が最大值となる。つまり、ある一定時間以上滑りが生じる と最大変位は $2 x_{\text {static }}$ である。この場合、二質点系の最大ベースシア

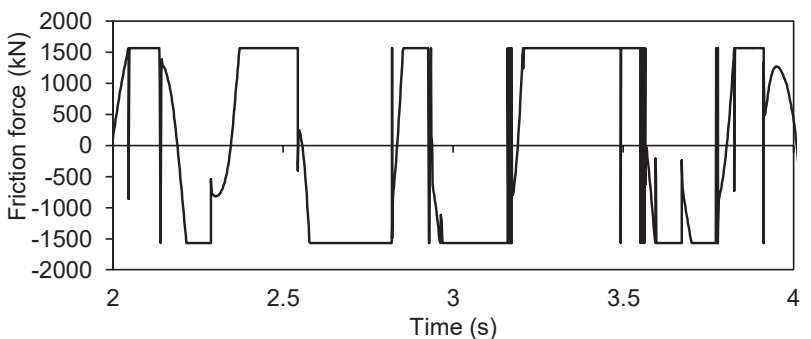

(a) Friction coefficient

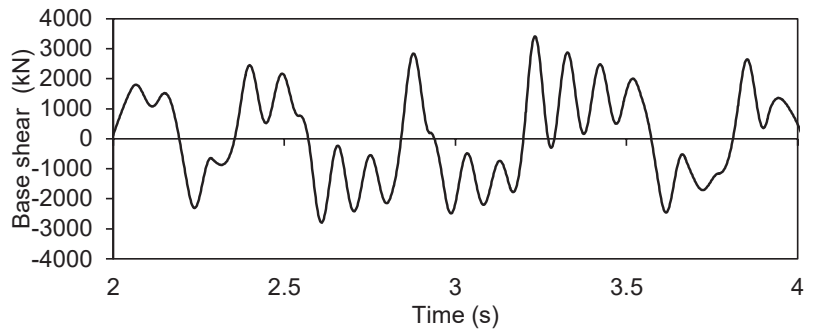

(b) Base shear

Fig. 10 Time history responses of la19 (Scale1)
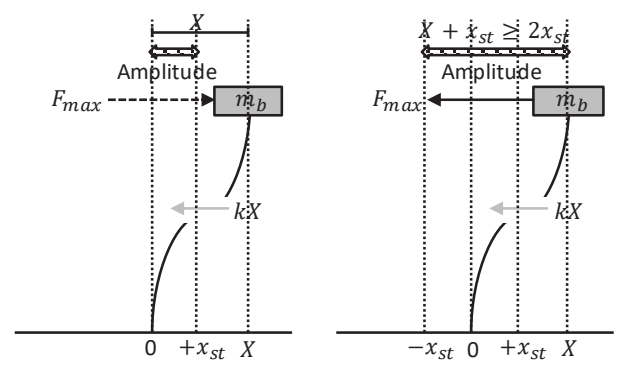

(a) Before amplification

(b) After changing direction of friction force

Fig. 11 Amplification of base shear

を $Q_{\max }$ とすると式(4)で求められる。

$$
Q_{\max }=K \times \max \left|\left(x_{b}-x_{1}\right)\right|
$$

ここでmax $\left|\left(x_{b}-x_{1}\right)\right|=2 x_{\text {static }}$ を代入して、式(5)となる。

$$
Q_{\max }=K \times 2 x_{\text {static }}
$$

$x_{\text {static }}=F_{\max } /\left(m_{1} /\left(m_{1}+m_{b}\right) K\right)$ を代入して整理すると

$$
Q_{\max }=2 \mu m_{1} \mathrm{~g}
$$

最大ベースシア係数を $C_{b, \max }$ とすると $Q_{\max }$ を上部重量 $m_{1} \mathrm{~g}$ で除した 值なので、式(7)となる。

$$
C_{b, \max }=2 \mu
$$

この值が最大ベースシア係数の上限值となる。このようにインパル ス入力の場合、最大ベースシア係数には上限值があり、その值は摩 擦係数の 2 倍である。

\section{3 パルス性地震動に対する応答}

$\mathrm{SAC} 20$ 地震動を漸増入力した二質点系の最大ベースシア係数を Fig.8(b)に示す。横軸はSAC20 の地震動に乗じた係数 Scale である。 Scale 1 は再現期間が 475 年、おおむね二次設計レベルに相当する。 図中の灰色の実線は 20 の地震動それぞれの最大応答であり、黒色 の実線は 84 パーセンタイル值である。Fig.8(b)の水平に二本引いた 一点鎖線は、摩擦係数 0.16 とその 2 倍である 0.32 を示している。 この図より、インパルス応答と同様の傾向を示しているものの、 パルス性地震動に対しては最大ベースシア係数は Scale が大きくな 
るにつれて摩擦係数の 2 倍を少し超える。図中の点線は 20 の地震 動のうちの最も大きな応答を示した la19 地震動に対する応答を示 す。

また Fig.10 に Scale1 の la19 に対する応答の一部で、Fig.10(a) は摩擦力、(b)はベースシアの時刻歴をそれぞれ示す。Fig.10(a)より 摩擦力が一定値になっている部分はその值は最大静止摩擦力 $F_{\text {max }}$ で あり、正負交互に変化している。つまり、滑り方向の反転が何度も 起きている。また、Fig.10(b)から摩擦力の反転の瞬間にベースシア の増幅が見られる。

Fig.11にベースシア増幅の模式図を示す。Fig.11(a)は滑り方向の 反転直前、Fig.11(b)は滑り方向の反転直後を示す。Fig.11(a)では、 最大静止摩擦力 $F_{\text {max }}$ が $m_{b}$ に正方向に作用している。この場合、 $m_{b}$ は $+x_{\text {static }}$ を中心に振動している。この時の $m_{b}$ の変位を $X$ とする。この 瞬間に最大静止摩擦力が反転したとすると Fig.11(b)のようになり、 新たな振動中心は $-x_{s t}$ となる。つまり摩擦力反転後の振幅は $x_{s t}+X$ となり、この振幅が静的変位 $x_{s t}$ の 2 倍以上であれば、最大べースシ ア係数も摩擦係数の 2 倍以上になる。このように、さまざまな大き さと周期成分を含む地震動に対しては、最大ベースシア係数に上限 值がある訳ではない。

前節で示した Fig.8(b)において 20 の地震動応答の 84 パーセンタ イル值(黒実線)に着目しScale1 は二次設計レベルに相当し、Scale1 の 1.5 倍を余裕度設計レベルと考えたとき、余裕度設計レベルに対 しては最大ベースシア係数は摩擦係数 0.16 の 2.3 倍、そのレベル以 上である二次設計レベルの 2 倍の地震動レベル（Scale2）に対して も摩擦係数の約 2.5 倍に概㸚収まっている。以上より、パルス性地 震動に対しては地震動レベルの増加とともに最大ベースシア係数は 緩やかに増加する傾向にあるが、余裕度設計レベルに対しては摩擦 係数の約 2.5 倍が上限となる。

\section{4. 非弾性系への適用}

\section{1 数值解析モデル}

勒性に乏しい建物でも崩壊までに多少の勒性を持っていることに 鑑み、塑性率を $2^{14)}$ まで許容した場合、前節で示した上限值を弾性 に留めるのに必要なベースシア係数がどの程度下げられるかを検証 する。

前章で用いた二質点系モデルにおいて、上部質量 $m_{1}$ と下部質量 $m_{b}$ 間のバネを非弾性系に変えたものを用い、降伏に達するべースシ ア係数を $C_{y}$ とし、 $C_{y}$ の值を変えて層間変形を検討する。ここで降伏 後の二次剛性は初期剛性 $\left(3.9 \times 10^{5} \mathrm{kN} / \mathrm{m}\right)$ の 0.01 倍とする。質量 比、固有周期、減衰定数及び摩擦係数は前章と同一で、それぞれ 0.9 、 0.3 秒、 $5 \% 、 0.16$ とした。

\subsection{SAC20 地震動入力に対する塑性率}

Scale2 の la19 地震動を入力した場合の二質点系の層間変形一べ ースシア関係を Fig.12 に示す。降伏ベースシア係数 $C_{y}$ は前章で得ら れた結論を参照して 0.4 とそれ以下の值（0.3、0.2、0.1）を採用し た。各図中には上部構造の最大変形を塑性率として記載している。

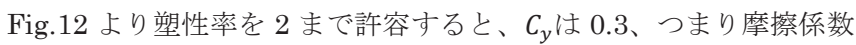
の 2 倍程度まで下げることができる。

同地震動レベルに対して他の 19 の地震動を入力した場合に得ら れる塑性率を Fig.13 に示す。図中の灰色マーカーは各地震動に対す

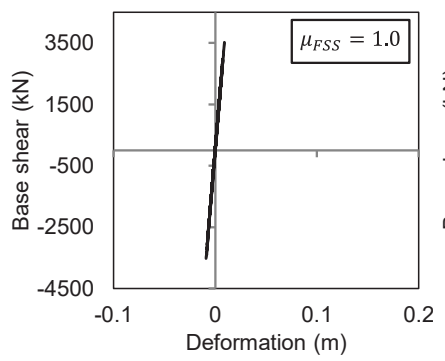

(a) $\mathrm{C}_{y}=0.4$

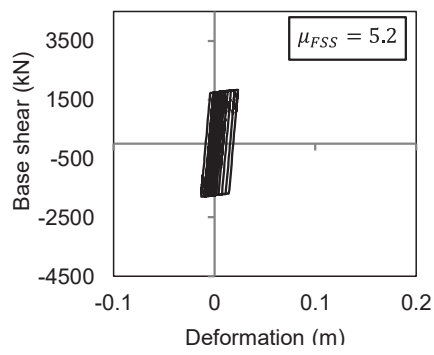

(c) $\mathrm{C}_{y}=0.2$

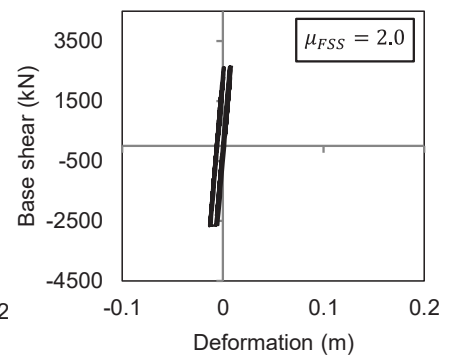

(b) $\mathrm{C}_{y}=0.3$

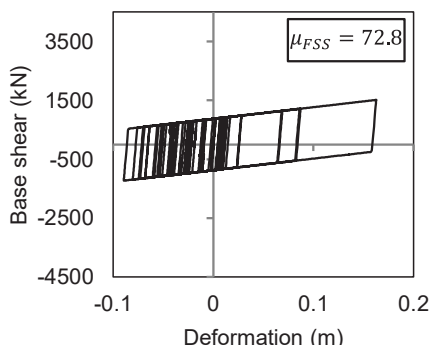

(d) $\mathrm{C}_{y}=0.1$
Fig. 12 Relationship between Base shear and Story drift (Scale2 of la19)

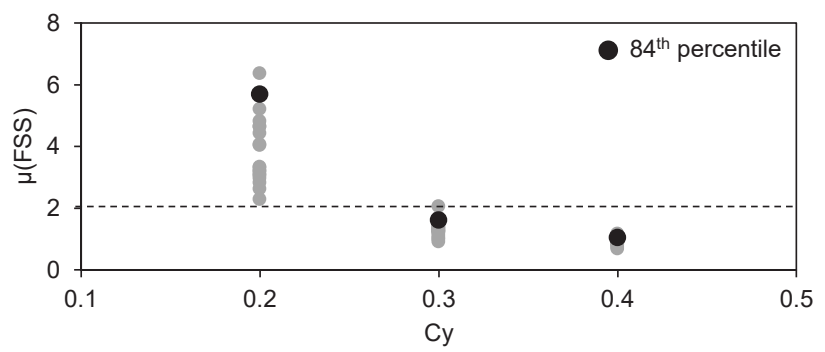

Fig. 13 Ductility ratios with respect to $C_{y}$ (SAC20) る塑性率の值、黒色マーカーは 84 パーセンタイル值である。他の 地震動を含めても塑性率を 2 まで許容すると前述の結論と変わらず、 直置き型構造の上部構造の耐力は摩擦係数の 2 倍程度でよい。

\section{5. 結論}

本研究では、極大地震動に対して建物への入力を制限することに よって倒壊を免れる耐震補強法として、建物柱脚と基礎間に滑りを 許容する直置き型構造を検討した。数值解析により、この構造に甚 大な被害を与える可能性の高いパルス性地震動に対する最大ベース シア係数を評価し、上部構造に必要な耐力と滑り時の摩擦係数との 関係を検証した。以下に得られた知見は下記の通りである。

1. 滑り 挙動の基本性能を評価するために、鋼と黒鉛潤滑剂を塗 布したモルタル間の摩擦係数の速度依存性や繰り返し滑りに 対する安定性を、振動台実験によって検証した。摩擦係数は、 滑り速度の増加とともに顕著な減少はみられず、実験による 累計滑り量は約 $20 \mathrm{~m}$ であったにもかかわらず、終始 0.16 で 安定していた。

2. 滑り時には高振動数 $\omega^{\prime}$ と高減衰 $\xi^{\prime}$ で振動していること、またこ の振動数は全体質量に対する上部質量の質量比に依存するこ とを実証した。 
3. 最大で $40 \%$ の軸力変動に対しても、加振中骨組試験体の寸べ ての柱脚は、同時に滑り出しまたほぼ等しい変位で滑るなど、 安定した滑り挙動を示した。

4. パルス性入力の基本性状を確かめるために用いたインパルス 入力に対して最大ベースシア係数に上限值があり、その值は 摩擦係数の 2 倍であることを数值解析により確認した。

5. パルス性地震動として 50 年超過確率が $10 \%$ ある SAC20 地 震動を漸増入力して最大ベースシア係数を評価した。インパ ルス応答と同様の傾向を示すものの、地震動レベルが大きく なるにつれて最大ベースシア係数は摩擦係数の 2 倍を少し上 回る。これは滑り時の反転によるベースシア増幅が原因であ ることを示した。

6. 20 の地震動に対する応答の 84 パーセンタイル值に着目する と、二次設計レベルの 1.5 倍に相当する余裕度設計レベルでの 最大ベースシア係数は摩擦係数の 2.3 倍、また二次設計レベル の 2 倍に相当する地震動レベルに対しても摩擦係数の約 2.5 倍に概㸚収まる。

7. 塑性率を 2 まで許容すると、二次設計レベルの 2 倍に相当す る地震動レベルのSAC20に対して上部構造に必要な耐力は摩 擦係数の 2 倍にまで下げることができる。

将来の課題として、直置き型構造の鉄骨造や壁式構造に適用する ためのさまざまな構法への適用と施工法の開発に取り組みたい。

\section{謝辞}

本研究の実施にあたり、ご協力いただいた Francesca Barbagallo 氏（イタリア国カターニャ大学）、Hongsong Hu 氏（中国華僑大 学）に心より感謝申し上げます。関連する振動台実験でご支援い ただいた京都大学防災研究所の山崎友也氏、川崎慎吾氏に厚く御 礼申し上げます。

\section{参考文献}

1) Mostaghel, N., Hejazi, M. and Tanbakuchi, J.: Response of Sliding Structures to Harmonic Support Motion, Earthquake Engineering and Structural Dynamics, Vol.11, pp.355-366, 1983.5

2) Mostaghel, N. and Tanbakuchi, J.:Response of Sliding Structures to Earthquake Support Motion, Earthquake Engineering and Structural Dynamics, Vol.11, pp.729-748, 1983.11

3) Pujol, S. and Fick, D.: The Test of a Full-Scale Three Storey RC Structure with Masonry Infill Walls, Earthquake Engineering and Structural Dynamics, Vol.32, pp.3112-3121, 2010.5

4) Dolsek, M. and Fajfar, P.: The Effect of Masonry Infills on the Seismic Response of a Four-Storey Reinforced Concrete Frame- A Deterministic Assessment, Engineering Structures,Vol.30, pp.1991-2001, 2008.7

5) McCormick, J., Nagae, T., Ikenaga, M., Zhang, P., Katsuo, M. and Nakashima, M.: Investigation of the Sliding Behaviour between Steel and Mortar for Seismic Applications in Structures, Earthquake Engineering and Structural Dynamics, Vol.38, pp.1401-1419, 2009.3

6) Enokida, R., Nagae, T., Ikenaga, M., Inami, M. and Nakashima, M. Application of Graphite Lubrication for Column Base in Free Standing Steel Structure, Journal of Structural and Construction Engineering (Transactions of AIJ), Vol.78, No.685, pp.435-444, 2013.3 (in Japanese)

榎田竜太, 長江拓也, 池永昌容, 稲美充顕, 中島正愛 : 黒鉛潤滑を応用 した直置き型鋼構造建物柱脚の摩擦低減, 日本建築学会構造系論文集, 第 78 巻，第 685 号，pp.435-444，2013.3
7) Barbagallo, F., Hamashima, I., Hu, H., Kurata, M., Nakashima, M.: Base Shear Capping Buildings with Graphite-Lubricated Bases for Collapse Prevention in Extreme Earthquakes, Earthquake Engineering and Structural Dynamics, 2016

8) Enokida, R., Nagae, T., McCormick, J., Katsuo, M. and Nakashima, M.: Shaking Table Test on Friction Behavior Between Steel Column Base and Base Mortar, Journal of Structural and Construction Engineering (Transactions of AIJ), Vol.73, No.629, pp. 1185-1191, 2008.7 (in Japanese)

榎田竜太, 長江拓也, ジェイソンマコーミック, 勝尾美香, 中島正愛 : 鋼構造露出柱脚と基礎モルタル間の摩擦性状に関する振動台実験、日本 建築学会構造系論文集，第 73 巻，第 629 号, pp.1185-1191，2008.7

9) Mazzoni, S., McKenna, F., Scott, M.H., Fenves, G.L. and Jeremic, B.,:OpenSEES Command Language Manual, Pacific Earthquake Engineering Research Center, University of California at Berkeley, USA, 2003

10) Scawthorn, C. and Chen, W.: Earthquake Engineering Handbook, CRC Press, 2002

11) Someville, P.G., Smith, N., Punyamurthula, S. and Sun, J.: Development of Ground Motion Time Histories for Phase 2 of the FEMA/SAC Steel Project. Report SAC/BD-97/04, SAC joint Venture, 1997

12) Chopra, A.K.: Response to Arbitrary, Step and Pulse Excitations, Dynamics Of Structures Theory And Applications To Earthquake Engineering second edition, Prince-Hall India, 2006

13) Shibata, A.: Saishintaishinkouzoukaiseki (Dynamic Analysis of Earthquake Resistant Structures), Morikita, 2003 (in Japanese) 柴田明徳：最新耐震構造解析 第二版, 森北出版株式会社, 2003

14) Fardis, M.N. and Panagiotakos, T.B.: Seismic Design and Response of Bare and Masonry-Infilled Reinforced Concrete Buildings Part II: infilled structures, Journal of Earthquake Engineering, Vol.1, No.3, pp.475-503, 1996.7 


\title{
SLIPPING BEHAVIOR OF BASE SHEAR CAPPING BUILDINGS FOR COLLAPSE PREVENTION AND REQUIRED MAXIMUM STRENGTH
}

\author{
Ikumi HAMASHIMA *, Masahiro KURATA ** and Masayoshi NAKASHIMA *** \\ * Grad. Student, Graduate School of Eng., Kyoto University \\ ** Assoc. Prof., DPRI, Kyoto University, Ph.D. \\ *** Prof., DPRI, Kyoto University, Ph.D.
}

In regions prone to earthquake-induced ground shaking, buildings with insufficient seismic capacity may suffer severe damage and in the worst case collapse. Collapse of buildings lead to loss of many human lives. Thus, collapse prevention of the buildings is the first priority in realizing earthquake-resilient community in such regions. This study proposes the concept of a base shear capped building for collapse prevention as one of promising seismic retrofits. The structural system detaches the superstructure from the foundation in order to prevent collapse by letting the superstructure slide under huge earthquakes. When small earthquakes occur, the proposed structure does not slide against the foundation and behave like a fixed-base structure. When huge earthquakes occur, the structure starts to slide because the horizontal force which develops between the sliding base and foundation exceeds the maximum static friction force.

The friction coefficient is one of key parameters in the sliding system. In this paper, graphite lubricant is used between steel and mortar, materials commonly used in building construction in order to obtain a target friction coefficient, 0.2 .

Previous numerical studies with a SDOF system revealed that the mass ratio, the weight of the superstructure over the total weight, was one of the ruling parameters. The objectives of this study are as follows: (1) Shaking table tests were conducted to evaluate the basic sliding behavior; and (2) The maximum base shear coefficient was estimated by numerical simulation when the proposed structure is subjected by pulse-type ground motions.

In the experimental part, two types of specimens were designed: a basic specimen that simulates a SDOF system having a sliding system and a frame specimen that consisted of beams and columns. With those specimens, the stability of friction coefficient and the effects of the mass ratio and the variation of axial forces on the sliding behavior were investigated.

Based on the test results, a simplified SDOF model featured with sliding behavior is developed, and the maximum base shear is estimated under pulse-type ground motions. Two types of input motions are used: an impulse motion and a set of SAC20 ground motions. Even if an existing building is brittle, it has some post-yielding ductility before collapse. To reflect this, additional numerical simulation is conducted using inelastic models and estimate the maximum required base shear coefficient when slight ductility, say two in ductility ratio, is permitted.

The major findings are as follows: (1) Experimental studies verified the stability of friction coefficient between steel and mortar lubricated with graphite powder throughout all loading cases, and the dynamic friction coefficient is 0.16. (2) Even when the variation of axial force reached 50\%, four column bases displaced equally, indicating that the effect of axial force variation on sliding behavior was minimal. (3) Numerical studies verified that there is an upper limit of the maximum base shear coefficient when the model is subjected to impulse motion, and the value of the upper limit is twice the friction coefficient. (4) For SAC20 ground motions, no obvious upper limit was present. However, even for earthquakes in level 2 (10 percent exceedance for 50 years), the maximum base shear coefficient remains at most 2.5 times the friction coefficient. (5) If slight ductility is permitted, the required maximum base shear coefficient can be reduced about twice the friction coefficient. 